\title{
Effect of dihydrotestosterone on follicular development, ovulation and reproductive capacity of mice
}

\author{
Tarala D. Nandedkar and Safia R. Munshi \\ Institute for Research in Reproduction, Parel, Bombay 400 012, India
}

\begin{abstract}
Summary. A single injection of a $5 \alpha$-dihydrotestosterone (DHT) was administered to cyclic female mice on the day of metoestrus. DHT $(1 \mathrm{mg})$ prolonged the dioestrous stage of the cycle by $24 \mathrm{~h}$ and there were $50 \%$ fewer large (normal) follicles than in oil-injected controls. Degenerating ova were observed in the oviduct of $70 \%$ of the DHT-treated mice and there was a significant reduction in the numbers of females becoming pregnant and bearing normal fetuses.
\end{abstract}

\section{Introduction}

Oestrogens are known to induce proliferation of granulosa cells (Pencharz, 1940; Paesi, 1952; Payne \& Hellbaum, 1955; Goldenberg, Vaitukitis \& Ross, 1972). Although the presence of testosterone receptors in the cytosol of granulosa cells has been reported (Schreiber, Reid \& Ross, 1976), the role of androgens in follicular development is still not clear. Hillier \& Ross (1979) have demonstrated that injection of testosterone induced degeneration of small follicles in immature rats, but the animals used were hypophysectomized and primed with oestrogen. These changes therefore need to be compared with events during a normal follicular cycle (Richards, 1979). A study was therefore undertaken with cyclic mice to observe the effects of dihydrotestosterone, a non-aromatizable androgen, on follicular development, ovulation and subsequent fertility.

\section{Materials and Methods}

The androgen, $5 \alpha$-androstan-17 $\beta$-ol-3-one ( $5 \alpha$-dihydrotestosterone: DHT), was obtained from Sigma Chemical Co. (St Louis, Missouri).

Normal cyclic mice of the Swiss strain, bred randomly in our Institute's colony were used for the study. The animals were maintained in air-conditioned rooms with a $14 \mathrm{~h}$ light/24 $\mathrm{h}$ schedule, and they were fed a standard laboratory diet and water ad libitum. The stage of the oestrous cycle was checked by assessment of daily vaginal smears.

\section{Experiment 1}

The absence of large preovulatory follicles in the rodent ovary during oestrus and metoestrus has been reported by Hirshfield \& Midgley (1978). DHT was therefore injected on the day of metoestrus to examine the effect on the development of large follicles.

On the day of metoestrus mice were injected subcutaneously with $100 \mu \mathrm{g}$ or $1 \mathrm{mg}$ DHT in $0.1 \mathrm{ml}$ olive oil. Controls were injected with $0.1 \mathrm{ml}$ olive oil. Each group consisted of 7-8 mice. 
The animals were killed $24 \mathrm{~h}$ after the injection. The ovaries were removed, cleaned, weighed to the nearest $0.1 \mathrm{mg}$ and fixed in $10 \%$ buffered formalin. Serial paraffin-wax sections were stained with Heidenhein's azan stain (Preece, 1959). Follicles in each section were classified as small, medium and large on the basis of the number of granulosa cells in the largest section of the follicle (Pedersen \& Peters, 1968). The small follicles were those containing $\leqslant 20$ granulosa cells (Type 3a). The medium and large follicles were further classified as normal or atretic, atretic follicles being those containing $>2$ granulosa cells with pycnotic nuclei (Hirshfield \& Midgley, 1978).

\section{Experiment 2}

On the day of metoestrus each of 20 cyclic mice were injected s.c. with $1 \mathrm{mg} \mathrm{DHT} \mathrm{in} 0.1 \mathrm{ml}$ olive oil and 20 controls were injected with $0.1 \mathrm{ml}$ olive oil. Vaginal smears were examined daily. Ten animals from each group were killed on the first day of oestrus. The ovaries were fixed and the oviducts were examined under the microscope for the presence of ova.

The other 10 animals of each group were mated with known fertile males on the day of pro-oestrus and checked for the presence of a copulatory plug on the following day (Day 1 of pregnancy). The mice were killed on Day 19 of pregnancy and the numbers of corpora lutea, fetuses and resorption sites were counted.

\section{Results}

\section{Experiment 1}

As shown in Table 1, there was a significant reduction in relative ovarian weight within $24 \mathrm{~h}$ of treatment with $1 \mathrm{mg} \mathrm{DHT}$ and a $50 \%$ reduction in the number of normal large follicles. The increase in the number of large atretic follicles was not significant. The follicle numbers in the other categories were similar in all the treatment groups.

Table 1. The effect of a single injection of DHT on ovarian weight and number of follicles in mice

\begin{tabular}{|c|c|c|c|c|c|c|c|}
\hline \multirow{2}{*}{$\begin{array}{l}\text { Treatment } \\
\text { (no. of mice) }\end{array}$} & \multirow{2}{*}{$\begin{array}{c}\text { Body } \\
\text { wt } \\
(\mathrm{g})\end{array}$} & \multirow{2}{*}{$\begin{array}{c}\text { Ovarian } \\
\text { wt } \\
\text { (mg/100 g } \\
\text { body wt) }\end{array}$} & \multicolumn{2}{|c|}{ Large follicles } & \multicolumn{2}{|c|}{ Medium follicles } & \multirow{2}{*}{$\begin{array}{c}\text { Small } \\
\text { follicles }\end{array}$} \\
\hline & & & Normal & Atretic & Normal & Atretic & \\
\hline Olive oil, & $17 \cdot 3$ & 42.43 & 7.25 & 9.00 & 13.34 & $2 \cdot 00$ & $132 \cdot 8$ \\
\hline $0.1 \mathrm{ml}(8)$ & \pm 0.69 & \pm 1.55 & \pm 0.75 & $\pm 1 \cdot 13$ & \pm 1.34 & \pm 0.53 & \pm 6.5 \\
\hline \multirow[t]{2}{*}{$\mathrm{DHT}, 100 \mu \mathrm{g}(7)$} & 17.6 & 42.00 & 6.57 & $7 \cdot 14$ & 14.00 & 3.71 & 127.0 \\
\hline & \pm 0.12 & \pm 1.66 & \pm 0.72 & \pm 0.96 & \pm 3.02 & \pm 0.68 & \pm 8.2 \\
\hline \multirow[t]{2}{*}{ DHT, $1 \mathrm{mg} \mathrm{(7)}$} & $17 \cdot 8$ & $35 \cdot 25^{*}$ & $3 \cdot 43^{*}$ & $10 \cdot 29$ & $18 \cdot 3$ & 1.43 & 138.2 \\
\hline & \pm 0.65 & \pm 1.70 & \pm 0.57 & $\pm 2 \cdot 84$ & \pm 2.91 & \pm 0.72 & \pm 9.4 \\
\hline
\end{tabular}

Values are mean \pm s.e.m.

* Significantly different from control values, $P<0.01$ ( $t$ test).

\section{Experiment 2}

On the first day of oestrus, most of the DHT-treated animals had degenerating ova in the oviducts (Table 2). Degenerating ova had no attached cumulus cells and some showed fragmentation of the cytoplasm. Normal as well as degenerating ova were located in the oviduct of 3 mice. In the tests of reproductive capacity of DHT-treated females, control and treated mice mated readily but the numbers of females becoming and remaining pregnant with live fetuses were affected by the DHT treatment (Table 3). The numbers of CL indicated that ovulation rate had been affected $\left(P<0.01, \chi^{2}\right)$. 
Table 2. Effect of a single injection of DHT on ovulation in cyclic mice

\begin{tabular}{lccccc}
\hline Treatment & $\begin{array}{c}\text { No. of } \\
\text { mice }\end{array}$ & $\begin{array}{c}\text { No. of mice } \\
\text { with normal } \\
\text { ova at } \\
\text { oestrus }\end{array}$ & $\begin{array}{c}\text { Mean } \pm \text { s.e.m. } \\
\text { no. of normal } \\
\text { ova/mouse }\end{array}$ & $\begin{array}{c}\text { No. of animals } \\
\text { with abnormal } \\
\text { ova(\%) }\end{array}$ & $\begin{array}{c}\text { Total no. of } \\
\text { degenerating/ } \\
\text { normal ova }\end{array}$ \\
\hline Olive oil, $0.1 \mathrm{ml}$ & 10 & 10 & $\begin{array}{c}8.5 \\
\pm 0.27 \\
4.9 \\
1.43^{*}\end{array}$ & 0 & $7 \dagger$ \\
DHT, $1 \mathrm{mg}$ & 10 & 3 & $26 / 49 \ddagger$ \\
\hline
\end{tabular}

* Significantly different from control value, $P<0.02$ ( $t$ test).

+3 mice had only abnormal ova.

$\ddagger$ Significantly different from control value, $P<0.01\left(\chi^{2}\right)$.

Table 3. Effect of a single injection of DHT on reproductive capacity of mice

\begin{tabular}{|c|c|c|c|c|c|c|c|}
\hline \multirow[b]{2}{*}{ Treatment } & \multirow[b]{2}{*}{$\begin{array}{l}\text { No. of } \\
\text { mice }\end{array}$} & \multicolumn{3}{|c|}{ No. of mice } & \multirow[b]{2}{*}{$\begin{array}{l}\text { Mean } \pm \text { s.e.m. } \\
\text { no. of normal } \\
\text { fetuses }\end{array}$} & \multirow{2}{*}{\multicolumn{2}{|c|}{$\begin{array}{l}\text { Total no. of } \\
\text { normal fetuses } \\
\text { total no. of } \\
\text { CL }(\%)\end{array}$}} \\
\hline & & $\begin{array}{l}\text { With normal } \\
\text { fetuses and no } \\
\text { resorption } \\
\text { sites on Day } \\
19 \text { of } \\
\text { pregnancy }\end{array}$ & $\begin{array}{l}\text { With } \\
\text { resorption } \\
\text { sites }\end{array}$ & $\begin{array}{c}\text { Not } \\
\text { pregnant }\end{array}$ & & & \\
\hline Olive oil, $0.1 \mathrm{ml}$ & 10 & 10 & 0 & 0 & $7.6 \pm 0.56$ & $76 / 79$ & (96) \\
\hline DHT, $1 \mathrm{mg}$ & 10 & 2 & $2 \dagger$ & $6 \ddagger$ & $2 \cdot 5^{*} \pm 1 \cdot 10$ & $25 / 33$ & (76) \\
\hline
\end{tabular}

* Significantly different from control value, $P<0.001$ ( $t$ test).

+ One resorption site and live fetuses in each female.

$\ddagger 2$ females showed dioestrous smears for 14 days, the other 4 had normal 4-day cycles.

\section{Discussion}

The $50 \%$ reduction in numbers of large normal follicles within $24 \mathrm{~h}$ of the injection of DHT is in agreement with the results of Payne \& Runser (1958) and Hillier \& Ross (1979) who demonstrated that testosterone propionate induced degeneration of ovarian follicles, although their observations (on hypophysectomized immature rats) related only to small follicles.

We observed an equal number of non-atretic and atretic large follicles in the ovaries of control mice. This is in agreement with the observations of Byskov (1974) who reported the ratio of non-atretic to atretic antral follicles to be between $1: 1$ and $1: 3$ in mice. Although there was no significant change in the normal and atretic medium-sized follicles in DHT-treated mice compared with controls, the reduction in the number of large follicles in the treated group was accompanied by an increase (not significant statistically) in the number of large atretic and medium-sized normal follicles, and the total number of medium-sized and large follicles in the control and DHT-treated mice were comparable (31.59 and 33.45 respectively).

Injection of DHT prolonged the dioestrous stage of the oestrous cycle by $24 \mathrm{~h}$ in all the animals and also decreased the number of normal ova in the oviduct on the day of oestrus. In adult rats, injection of dehydroepiandrosterone (DHA) caused ovarian failure and polycystic ovarian changes within a day of treatment (Parker \& Mahesh, 1976). Gnodde, van Dieten \& Van Look (1979) have also observed that administration of androstenedione, a weak androgen, to rats prolonged the dioestrous stage and caused a reduction in the number of ova in the oviducts; they did not, however, report whether the ova were abnormal. Androstenedione is a precursor for oestrogen synthesis, while DHT is a non-aromatizable androgen. This and also the species difference may account for the different result in the present study. The reason for the 
degeneration is unknown, but could be due to reduced protein synthesis in the follicle (Siracusa, Whittingham, Molinaro \& Vivarelli, 1978).

Injection of DHT in cyclic mice reduced the ovarian weight and inhibited follicular development within $24 \mathrm{~h}$. DHT may have a direct action on the ovary; testosterone receptors are known to be present in the cytosol of the granulosa cells (Schreiber et al., 1976).

We thank Mr P. K. Balachandran and Mr S. T. Ghanekar for their excellent technical assistance, and $\mathrm{Mr}$ C. P. Prakasam for statistical analysis.

\section{References}

Byskov, A.G. (1974) Cell kinetic studies of follicular atresia in the mouse ovary. J. Reprod. Fert. 37, 277-285.

Gnodde, H.P., van Dieten, J.A.M.J. \& Van Look, P.F.A. (1979) Effect of androstenedione on the oestrous cycle of the rat. J. Reprod. Fert. 56, 675-678.

Goldenberg, R.L., Vaitukitis, J.L. \& Ross, G.T. (1972) Estrogen and FSH interaction on follicle growth in rats. Endocrinology 90, 1492-1498.

Hillier, S.G. \& Ross, G.T. (1979) Effect of exogenous testosterone on ovarian weight, follicular morphology and intraovarian progesterone concentration in estrogen-primed hypophysectomized immature female rats. Biol. Reprod. 20, 261-268.

Hirshfield, A.N. \& Midgley, A.R., Jr (1978) Morphometric analysis of follicular development in the rat. Biol. Reprod. 19, 597-605.

Paesi, F.J.A. (1952) The effect of small doses of estrogen on the ovary of the immature rat. Acta endocr., Copenh. 11, 251-268.

Parker, C.R. \& Mahesh, V.B. (1976) Interrelationship between excessive levels of circulating androgens in blood and ovulatory failure. J. Reprod. Med. 17, 75-90.

Payne, R.W. \& Hellbaum, A.A. (1955) The effect of estrogen on the hypophysectomized rat. Endocrinology 57, 193-199.
Payne, R. W. \& Runser, R.H. (1958) The influence of estrogen and androgen on the ovarian response of hypophysectomized immature rats to gonadotropins. Endocrinology 62, 313-321.

Pedersen, T. \& Peters, H. (1968) Proposal for a classification of oocyte and follicles in the mouse ovary. J. Reprod. Fert. 17, 555-557.

Pencharz, R. I. (1940) Effect of estrogens and androgens alone and in combination with chorionic gonadotropins on the ovary of the hypophysectomized rat. Science, N.Y. 91, 554-555.

Preece, A. (1959) Mannual for Histologic Technicians, pp. 190-191. J. A. Churchill Ltd, London.

Richards, J.S. (1979) Discussion summary: Session on follicular hormone receptors. In Ovarian Follicular Development and Function, pp. 265-266. Eds A. R. Midgley, Jr \& V. A. Sadler. Raven Press, New York.

Schreiber, J.R., Reid, R. \& Ross, G.T. (1976) A receptor-like testosterone binding protein in ovaries from estrogen stimulated hypophysectomized immature female rats. Endocrinology 98, 1206-1213.

Siracusa, G., Whittingham, D.G., Molinaro, M. \& Vivarelli, E. (1978) Parthenogenetic activation of mouse oocytes induced by inhibitors of protein synthesis. J. Embryol. exp. Morph. 43, 157-166.

Received 12 May 1980 